\title{
EFEK PENAMBAHAN EKSTRAK RUMPUT LAUT Eucheuma Cottonii PADA PEMBUATAN ES BATU TERHADAP KEMUNDURAN MUTU KERANG LOKAN (Geloina erosa) DAN KERANG DARAH (Anadara granosa)
}

\author{
The Effect of Eucheuma cottonii Seaweed Extract addition in Ice Cubes production Against \\ the Deterioration Quality of Geloina erosa and Anadara granosa \\ Habsah Agusnia ${ }^{1)}$, Kiki Fatmawati ${ }^{\left.{ }^{*}\right)}$, Made Suhandana ${ }^{2)}$ \\ 1)Jurusan Teknologi Hasil Perikanan, Fakultas IImu Kelautan dan Perikanan Universitas \\ Maritim Raja Ali Haji, Tanjungpinang, 29111, Indonesia \\ ${ }^{2)}$ Dinas Kelautan dan Perikanan Provinsi Sumatera Selatan, Palembang, 20257, Indonesia \\ *korespondensi: kikifa99@gmail.com
}

Diterima : 10 Oktober 2020; Disetujui : 27 April 2021

\begin{abstract}
Phylum molusca is a group of animals that are soft-bodied and have no spine (invertebrates). One of the phylum molusca is a class of Bivalvia that is generally in the form of lateral symmetry, a type of bivalvia that is often found in the water of Riau Islands is Lokan shells (Geloina erosa) and Darah shells (Anadara granosa) that live in tidal areas. The purpose of this study is to find out if the addition of water ice cubes resulting from the extraction of seaweed Echeuma Cottonii is effective for lokan shells and blood shells. Based on the results of the study obtained for the meat rendment of each shell is $85.39 \%$ in lokan shells and $84.27 \%$ in darah shells. Organoleptic results showed a more effective treatment of shellfish treatment with the addition of regular ice cubes, Water Holding Capacity (WHC) for the treatment of water ice cube extract binding or absorbing more water than regular ice cube treatment. The second $\mathrm{pH}$ of shellfish from three treatments had a value below 7 , the lowest acidic $\mathrm{pH}$ obtained treatment with seaweed ice cubes.
\end{abstract}

Keywords: Anadara granosa, Geloina erosa, $\mathrm{pH}, \mathrm{WHC}$

\begin{abstract}
ABSTRAK
Filum molusca merupakan suatu kelompok hewan yang bertubuh lunak dan tidak memiliki tulang belakang (avertebrata). Salah satu dari Filum molusca adalah kelas Bivalvia yang umumnya berbentuk simetri lateral, jenis bivalvia yang sering dijumpai diperairan Kepulauan Riau adalah kerang lokan (Geloina erosa) dan kerang darah (Anadara granosa) yang hidup di daerah pasang surut. Tujuan dari penelitian ini adalah mengetahui apakah penambahan es batu air hasil ektraksi rumput laut Echeuma Cottonii tersebut efektif untuk kerang lokan dan kerang darah. Berdasarkan hasil penelitian didapatkan untuk rendemen daging dari masing-masing kerang adalah $85,39 \%$ pada kerang lokan dan $84,27 \%$ pada kerang darah. Hasil organoleptik menunjukkan perlakuan yang lebih efektif perlakuan kerang dengan penambahan es batu biasa, Water Holding Capacity (WHC) untuk perlakuan es batu air ekstrak mengikat atau menyerap lebih banyak air daripada perlakuan es batu biasa. $\mathrm{pH}$ kedua kerang dari tiga perlakuan memiliki nilai dibawah $7, \mathrm{pH}$ asam terendah didapatkan perlakuan dengan es batu air esktrak rumput laut.
\end{abstract}

Kata kunci: Kerang Darah, Kerang Lokan, pH, WHC

\section{PENDAHULUAN}

Filum molusca merupakan suatu kelompok hewan yang bertubuh lunak dan tidak memiliki tulang belakang (avertebrata), salah satu dari Filum molusca adalah kelas Bivalvia yang umumnya berbentuk simetri lateral, cangkang terdiri dari dua katup dan kedua katup cangkang dihubungkan oleh suatu engsel pada bagian dorsal (ligament) dan di tutup dan dibukakan oleh sepasang otot abductor. Sebagian besar kelompok hewan ini mempunyai cara makan dengan 
memfilter bahan organik yang tersuspensi di perairan filter-feeder dengan menggunakan insangnya. jenis bivalvia yang sering dijumpai adalah kerang Lokan (Geloina erosa) dan kerang Darah (Anadara granosa) yang hidup di daerah pasang surut (Hasan, 2017).

Kerang Lokan merupakan kerang bivalvia yang hidup di kawasan mangrove dengan ukuran dapat mencapai $11 \mathrm{~cm}$ (Gimin et al., 2004). Kerang ini telah dikonsumsi oleh masyarakat Pulau Enggano, dan mempunyai kandungan gizi yang tinggi dengan komposisi protein sebesar 7,06\%-16,87\%, lemak sebesar 0,40-2,47\%, karbohidrat sebesar 2,36-4,95\% serta memberikan energi sebesar 69-88 $\mathrm{kkal} / 100$ gram daging. Dengan memperhatikan potensinya sebagai sumber protein hewani, kerang tersebut perlu dipertimbangkan pengembangannya (Suaniti 2007).

Kerang Darah (Anadara granosa) merupakan salah satu jenis kerang yang memiliki nilai ekonomis dan kandungan gizi yang tinggi. Kerang Darah kaya akan kandungan protein dan mineral yang berpotensi dalam memenuhi kebutuhan pangan masyarakat Indonesia. Perairan Indonesia memiliki potensi yang sangat besar untuk produksi kerang. Berdasarkan data statistik kementerian kelautan dan perikanan tahun 2017, volume produksi kerang (kerang Darah, kerang Lokan) sebesar $57.537,79$ ton dan tahun 2018 sebesar $94.708,84$ ton.

Sampai saat ini pemanfaatan kerang darah hanya sebatas konsumsi saja. Padahal kerang dikenal sebagai sumber pangan protein berkualitas tinggi. Nurjanah et al. (2010) menyebutkan bahwa dalam daging kerang Darah terkandung protein yang tinggi sebesar $19,48 \%$ dapat dimaksimalkan pemanfaatannya dengan membuat konsentrat protein untuk pengembangan produk olahan perikanan.
Bahan baku perikanan memiliki kelemahan, yaitu mudah mengalami kerusakan atau kemunduran mutu. Proses kemunduran mutu kerang akan terus berlangsung apabila tidak dihambat. Faktor yang dapat mempengaruhi cepatnya kemunduran mutu kerang bisa disebabkan oleh faktor internal kerang itu sendiri maupun dan faktor eksternal yang berkaitan dengan lingkungan dan penanganan. Sistem rantai dingin adalah suatu penanganan untuk mempertahankan mutu kerang (Zakaria, 2008). Menurut Stein et al. (2005), penyimpanan suhu rendah dapat memperpanjang daya awet hingga mencapai 1-4 minggu.

Eucheuma cottonii memiliki komposisi makro protein $5,12 \%$, lemak $0,13 \%$, karbohidrat $13.38 \%$, serat $1,39 \%$, abu $14,21 \%$, air $12,9 \%$, dan karagenan $65,7 \%$. Komposisi kandungan micro rumput laut adalah mineral esensial (besi, iodin, aluminum, mangan, kalsium, nitrogen, phosphor, sulfur, klor, silikon, rubidium, strontium, barium, titanium, kobalt, boron, tembaga, kalium, dan unsur-unsur lainnya), asam nukleat, asam amino, protein, mineral, tepung, gula dan vitamin $A, D, C, D E$, dan $\mathrm{K}$.

Seperti yang kita ketahui Eucheuma cottonii atau rumput laut sangat baik dan aman untuk tubuh, maka dari itu peneliti ingin menjadikan rumput laut Echeuma cottonii sebagai bahan penambah pembuatan es batu untuk mengawetkan kerang tersebut. Flavonoid pada rumput laut Eucheuma cottonii merupakan senyawa kimia hasil proses metabolit sekunder yang dapat menghasilkan aktivitas antibakteri (Iskandar et al. 2009). Menurut Sartika et al. (2013), ekstrak rumput laut Echeuma cottonii memiliki aktivitas antibakteri yang menghambat pertumbuhan bakteri dengan konsentrasi maksimum Staphylococcus aureus yaitu 17,33 mm, Escherichia coli $16,33 \mathrm{~mm}$, Vibrio cholera 13, $67 \mathrm{~mm}$ dan 
Salmonella typhosa $11,67 \mathrm{~mm}$. Nilai zona hambat ekstrak Eucheuma cottonii dapat dikategorikan dalam kategori kuat. Tujuan penelitian ini adalah mengetahui apakah penambahan es batu air hasil ektraksi rumput laut Echeuma Cottonii tersebut efektif untuk kerang Lokan dan kerang Darah.

\section{METODE PENELITIAN}

\section{Waktu dan Tempat}

Penelitian dilakukan pada bulan JuliAgustus 2020 di Fakultas IImu Kelautan dan Perikanan. Pengambilan sampel rumput laut Eucheuma cottonii dilakukan di pasar Koperasi Unit Desa Tanjungpinang dan pengambilan sampel Kerang Lokan (Geloina Erosa) dan Kerang Darah (Anadara granosa) dilakukan di Tanjung Unggat. Dilanjutkan dengan proses preparasi sampel di Laboratorium Fakultas IImu Kelautan daan Perikanan Universitas Maritim Raja Ali Haji (UMRAH).

\section{Bahan dan Alat}

Alat-alat yang digunakan untuk pengujian kemunduran mutu ini yaitu blender, lembar scoresheet, kompor/oven, termometer air raksa/digital, timbangan analitik, $\mathrm{pH}$ meter, pengukus, kertas saring, lempengan kaca. Bahan utama dalam penelitian ini adalah kerang Lokan (Goloina erosa), dan kerang Darah (Anadara granosa) sedangkan bahan tambahan terdiri dari rumput laut Eucheuma cottonii, dan aquades.

\section{Metode Penelitian}

Metode ini dilakukan dengan dua tahap yaitu tahap pembuatan ekstrak es batu rumput laut dan tahap pengujian. Dalam penelitian ini dilakukan dengan tiga perlakuan yaitu es batu hasil ektraksi

\section{Uji Organoleptik (SNI 01-2346-2006)}

Uji organoleptik yang digunakan adalah uji mutu hedonik menggunakan panelis semi terlatih sebanyak 5 panelis. Uji mutu hedonik tidak menyatakan suka atau tidak suka melainkan menyatakan kesan tentang baik atau buruk. Kesan baik atau buruk ini disebut kesan mutu hedonik. Oleh karena itu beberapa ahli memasukkan uji mutu hedonik ini kedalam uji hedonik. Kesan mutu hedonik lebih spesifik dari pada sekedar kesan suka atau tidak suka.

\section{Water Holding Capacity (WHC)}

Pengujian Water Holding Capacity (WHC) mengacu pada prosedur pengujian menurut Alimuddin, (2013). Prosedur pengujian adalah sebagai berikut: Menyiapkan bahan dan alat. Sampel yang akan di analisis ditimbang sebanyak 0,3 gram di atas kertas saring yang sudah ditera. Sample tersebut diletakkan di antara dua lempengan kaca. Memberikan beban sebesar $35 \mathrm{~kg}$ selama 5 menit. Setelah 5 menit beban disingkirkan serta lempengan kaca di atasnya juga disingkirkan, maka akan terlihat sampel daging menjadi rata dan ada luas daerah basah di sekitar daging yang basah. Diberikan tanda pada daerah yang basah dan daerah daging dengan menggunakan plastik transparan kemudian mengukur luasnya dengan menggunakan kertas millimeter $(\mathrm{mm})$ blok. Daya mengikat air dihitung dengan rumus sebagai berikut :

$$
\text { Mg } H_{2} \mathrm{O}=\frac{\text { Daerah basah }\left(\mathrm{cm}^{2}\right)}{0.0948}-8.0
$$

\section{Pengukuran Nilai pH}

Menurut Suwetja (2007), bahwa penentuan $\mathrm{pH}$ dapat dilakukan dengan menggunakan $\mathrm{pH}$ meter. Sampel yang telah dirajang kecil-kecil timbang sebanyak $10 \mathrm{~g}$ lalu homogenkan menggunakan mortar dengan $20 \mathrm{ml}$ aquades selama 1 menit. 
Selanjutnya tuangkan kedalam beker glass $10 \mathrm{ml}$, kemudian diukur $\mathrm{pH}$-nya dengan menggunakan $\mathrm{pH}$ meter. Sebelum $\mathrm{pH}$ meter digunakan, harus ditera kepekaan jarum penunjuk dengan larutan buffer $\mathrm{pH} 7$. Besarnya $\mathrm{pH}$ adalah pembacaan jarum penunjuk $\mathrm{pH}$ setelah jarum skala konstan kedudukannya.

\section{HASIL DAN PEMBAHASAN}

\section{Rendemen}

Rendemen merupakan bagian tubuh kerang yang dapat dimanfaatkan, rendemen pada kerang biasa terbagi 3 kelompok yaitu cangkang, daging dan jeroan. Rendemen sendiri merupakan hasil dari perhitungan bobot dibagi bobot total dikali $100 \%$. Untuk hasil rendemen kedua biota kerang dapat dilihat pada Gambar 1.

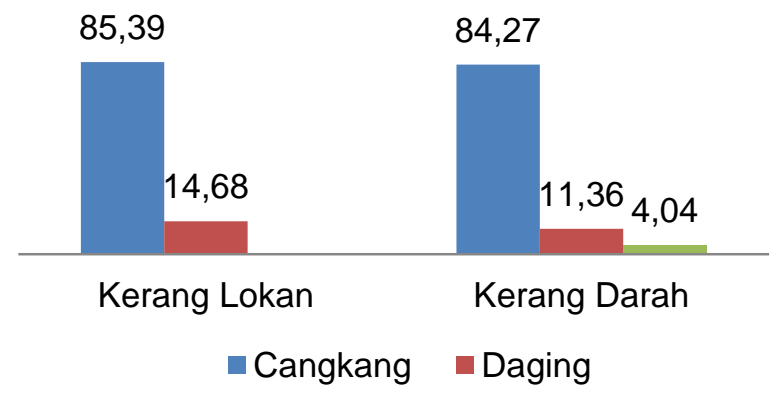

Gambar 1. Rendemen Kerang Lokan dan Kerang Darah

Berdasarkan pada Gambar 1 dapat diketahui besarnya rendemen persentase rendemen daging rendemen dari kedua biota kerang diketahui besarnya persentase rendemen daging kerang Lokan $14.68 \%$ dan cangkang $85.39 \%$, Terjadinya proses penambahan panjang cangkang, berat total dan kematangan gonad sesuai dengan pertambahan umur Geloina erosa (Widowati et al. 2005). Dan besarnya persentase rendemen daging kerang Darah 11.36\%, cangkang $84.27 \%$ dan jeroan $4.04 \%$. Dapat terlihat dari kedua biota kerang tersebut rendemen cangkang adalah yang paling besar.

Kerang memiliki rendemen yang sangat tinggi terdapat pada rendemen cangkang karena bagian cangkang pada kerang menutupi tubuh kerang yang disebut daging dalam cangkang. Menurut Rasidi et al. (2007) rendemen daging kerang darah sebesar $11 \%$.

\section{Organoleptik}

Organoleptik merupakan pengujian terhadap bahan makanan berdasarkan kesukaan dan kemauan untuk mempergunakan suatu produk. Uji Organoleptik atau uji indera atau uji sensori sendiri merupakan cara pengujian dengan menggunakan indera manusia sebagai alat utama untuk pengukuran daya penerimaan terhadap produk. Pengujian organoleptik mempunyai peranan penting dalam penerapan mutu. Pengujian organoleptik dapat memberikan indikasi kebusukan, kemunduran mutu dan kerusakan lainnya dari produk. Uji organoleptik diamati selama 24 jam dengan waktu 3 jam sekali. Parameter yang diamati dalam mengamati kemunduran mutu kerang adalah kenampakan, bau, tekstur dengan 3 perlakuan.

\section{Kenampakan}

Kenampakan merupakan parameter organoleptik yang cukup penting dinilai oleh panelis. Kenampakan juga mempengaruhi penerimaan konsumen terhadap produk, meskipun kenampakan tidak menentukan tingkat kesukaan konsumen secara mutlak. Hasil pengamatan kenampakan dari dua biota kerang terdapat pada Gambar 2 dan 3. 


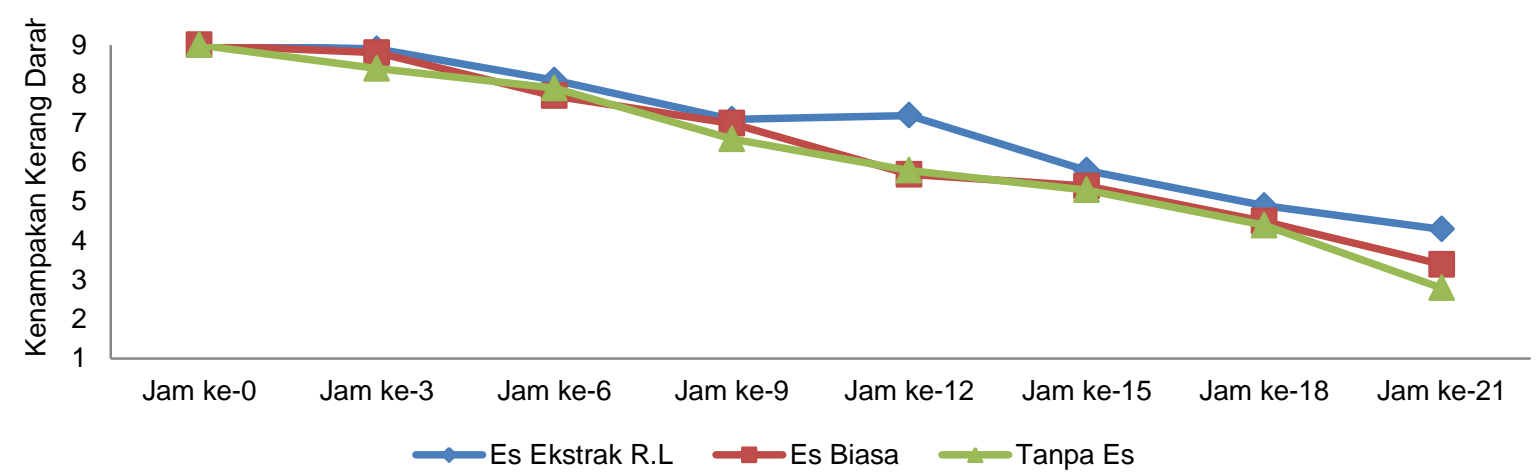

Gambar 2. Kenampakan Kerang Darah

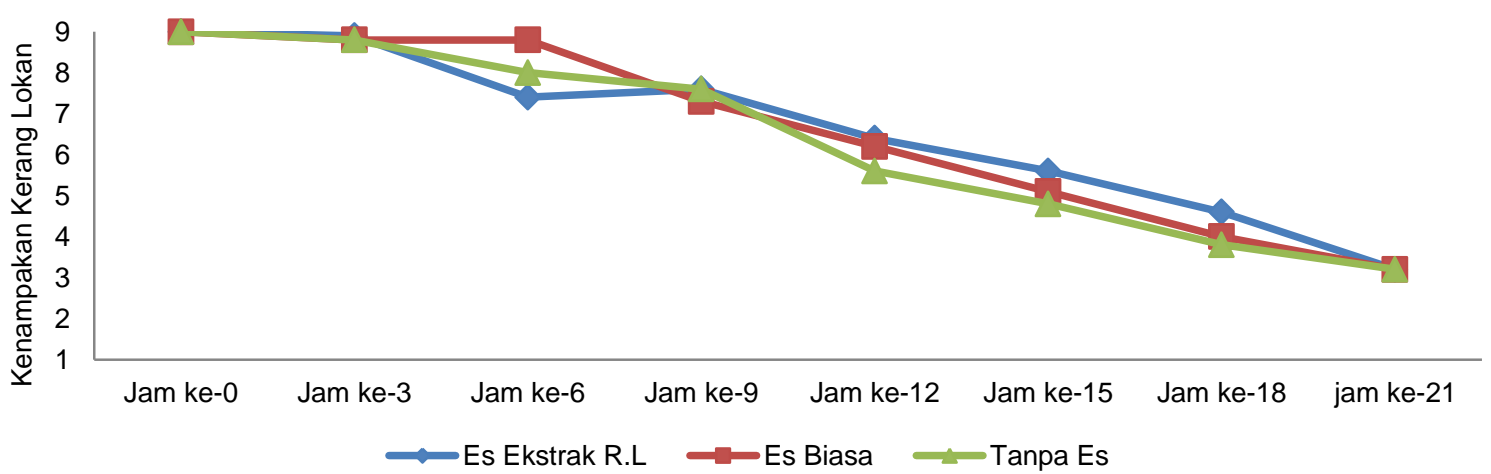

Gambar 3. Kenampakan Kerang Lokan

Berdasarkan Gambar kenampakan kerang Darah memiliki penurunan pada perlakuan es batu air ekstrak dari jam ke-0 hingga jam ke-12 dengan nilai 9-7.2 yang berarti kenampakan masih ditahap segar mengacu pada BSN (2009) karena standart kesegaran minimal bernilai 7. Berdasarkan penelitian yang telah dilakukan sebelumnya oleh Iskandar et al. (2005), senyawa bioaktif yang terkandung dalam mikro alga Eucheuma cottonii dapat berperan sebagai senyawa antibakteri yang memungkinkan dapat menghambat pertumbuhan bakteri patogen pada manusia, seperti $B$. Subtilis. Ektrak alga merah menghambat pertumbuhan bakteri, baik itu gram positif maupun gram negatif dan bioaktivitas ektrak alga merah Eucheuma cottonii cenderung bersifat bakteriostatik (Dwyana dan Johannes, 2012). Penelitian Hafizah (2015) juga menjelaskan bahwa hasil uji daya hambat ekstrak Eucheuma cottonii terhadap bakteri uji menunjukkan adanya respon hambatan pertumbuhan bakteri terhadap Staphylococcus aureus. Kerang Darah pada jam ke-0 sampai jam ke-12 dengan perlakuan es batu ekstrak rumput laut masih terlihat segar karena es batu pada jam tersebut masih utuh dan hanya mencair sedikit ini menyebabkan kenampakan kerang masih terlihat bagus dijam tersebut. Kerang Darah dengan perlakuan penambahan es batu biasa dilihat dari jam ke-0 hingga jam ke-9 nilai yang didapat 9-7 yang berarti kerang masih segar dan mengalami kemunduran pada jam ke-12 hingga jam ke-21, untuk perlakuan terakhir yaitu dengan perlakuan kerang tanpa penambahan es batu dari jam ke-0 hingga jam ke-6 kerang masih terlihat segar dan mengalami kemunduran pada jam ke-9. 
Menurut Winarno (2002), penurunan kenampakan dikarenakan aktivitas bakteri.

Berbeda dari kerang Darah pada hasil organoleptik kerang Lokan, dimana penurunan pada perlakuan es batu air ekstrak rumput laut dari jam ke-0 hingga jam ke-9 saja dengan nilai 9-7.6. pada es biasa dari jam ke-0 hingga jam ke-9 menurun dari 9-7,3 dan untuk kerang tanpa es dari jam ke-0 sampai jam ke-9 menurun dari 9-7,6. Nilai organoleptik pada waktu pengujian ke5 hingga ke-8 mengalami penurunan kesegaran secara perlahan. Rochima dan Rizki (2009) kenampakan mempengaruhi penerimaan panelis.

Mikroorganisme yang terdapat pada saluran pencernaan (jeroan) mengakibatkan kerang dalam kondisi utuh lebih cepat mengalami proses kemunduran mutunya karena bakteri dalam jeroan dengan cepat menyerang bagian-bagian tubuh biota tersebut (Irianto dan Giyatmi 2009).

\section{Bau}

Bau atau aroma dari suatu produk makanan mempunyai peranan penting dalam penilaian dan penampilannya karena apabila makanan tersebut mempunyai aroma yang khas maka produk tersebut dikatakan baik. Aroma yang kurang khas pada suatu produk makanan dapat mengakibatkan kurang disukainya produk makanan tersebut. Menurut Zuhrina (2011), aroma yang disebarkan oleh makanan merupakan daya tarik yang sangat kuat dan mampu merangsang indera penciuman sehingga membangkitkan selera. Pengamatan bau dari kedua biota kerang dapat dilihat dari Gambar 4 dan 5.

Berdasarkan Gambar bau hasil pengujian kerang darah dengan perlakuan penambahan es batu air ekstrak rumput laut pada jam ke-0 hingga jam ke-6 memiliki nilai 8.6-7 yang berarti berbau segar dan mulai kemunduran bau pada jam ke- 9 dengan nilai 6.5 , kemudian kerang dengan perlakuan penambahan es batu biasa pada jam ke-0 hingga jam ke-9 memiliki nilai 8.66.9 mendekati segar, dan daging kerang dengan perlakuan tanpa es pada jam ke-0 hingga jam ke-3 aroma daging masih berbau segar, dan mengalami kemunduruan lebih awal yaitu sejak jam ke-6.

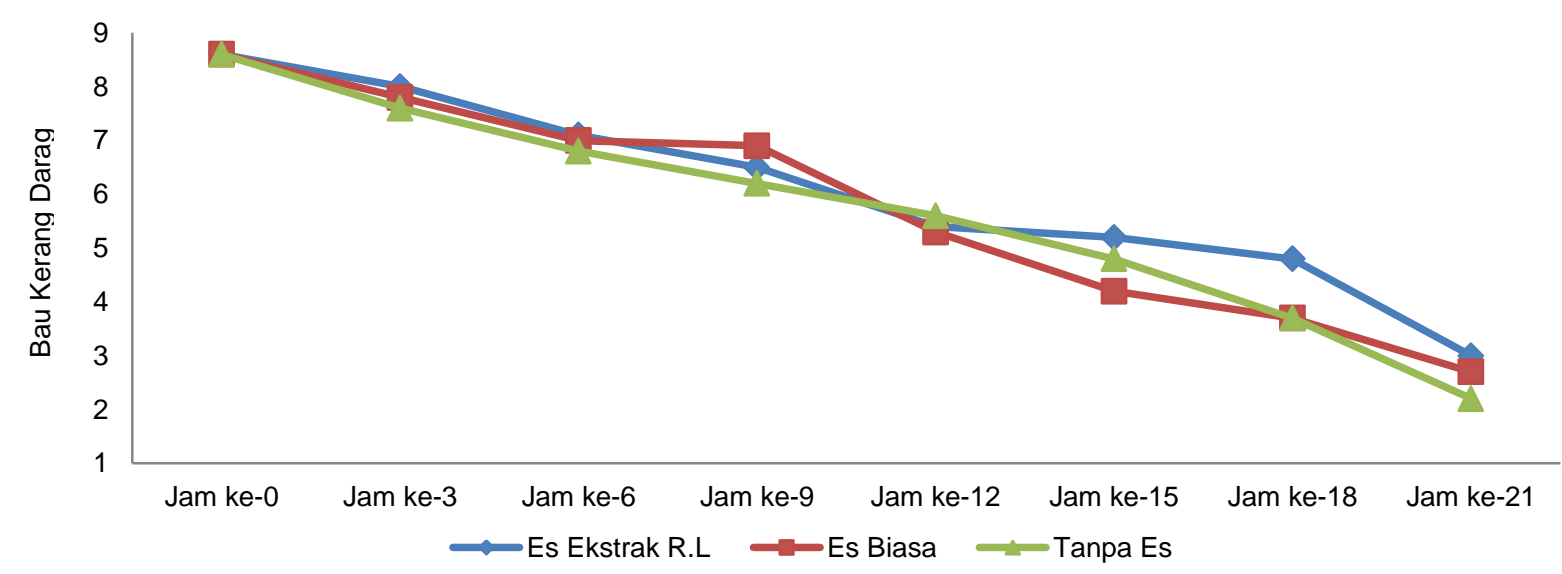

Gambar 4. Bau Kerang Darah 


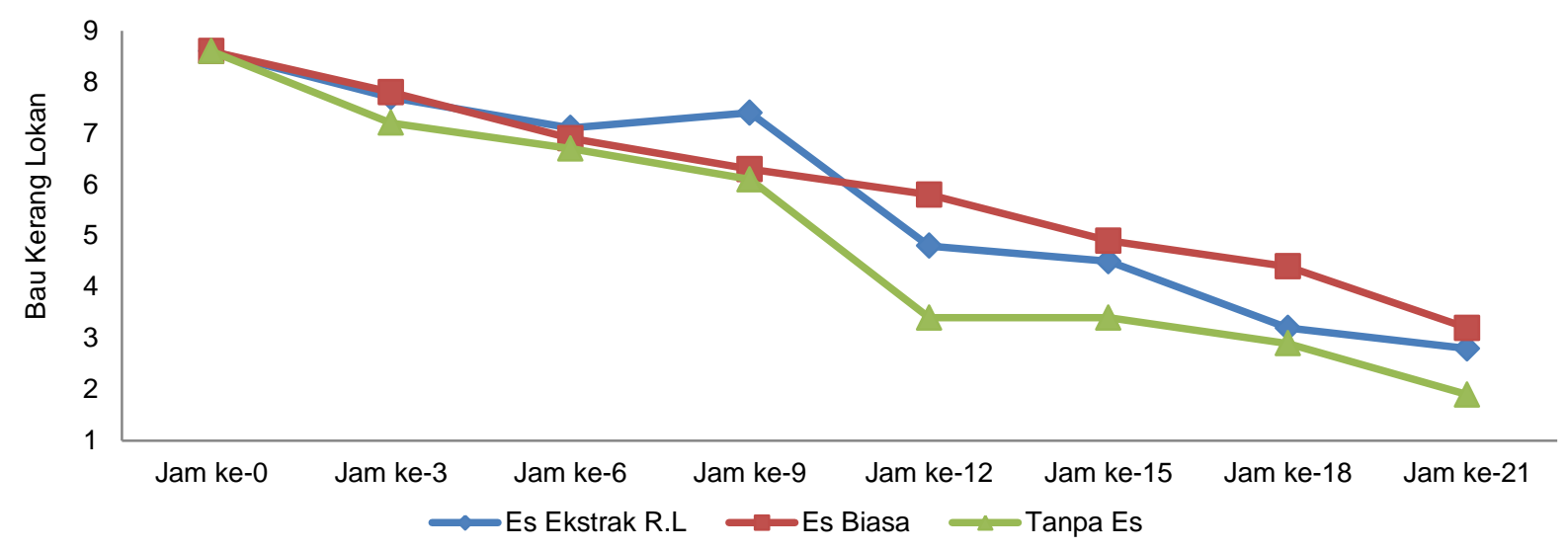

Gambar 5. Bau Kerang Darah

Kemudian untuk Gambar bau pengujian kerang lokan menunjukkan bahwa dari jam ke-0 sampai jam ke-9 pada kerang yang menggunakan es ekstrak rumput laut masih terlihat segar karena penurunan nilai dari angka 8,6 menjadi 7,4 dan pada kerang yang menggunakan es biasa hanya dari jam ke-0 sampai jam ke-3 yang terlihat segar dari angka 8,6 menurun menjadi 7,8, dan pada kerang yang tidak menggunakan es juga dari jam ke-0 sampai jam ke-3 yang terlihat segar dari angkaa 8,6 menjadi 7,2. Berdasarkan data tersebut dapat diketahui bahwa pada kerang es ekstrak rumput laut jam ke-5 sampai jam ke-8 tidak segar lagi dan pada kerang es biasa serta tanpa es tidak segar terdapat pada jam ke-6 sampai jam ke-21.

Mengacu pada BSN, (2009) bau daging yang masih diterima konsumen minimal bernilai 7. Jadi untuk nilai pada penilaian organoleptik Bau didapatkan bahwa kerang Darah mendapatkan hasil terbaik pada perlakuan es batu biasa dan untuk kerang Lokan hasil terbaik didapatkan dengan perlakuan es ekstrak rumput laut. Aroma berhubungan dengan komponen volatil dari suatu bahan, semakin banyak komponen volatil yang terdapat pada suatu bahan maka aroma yang terbentuk akan lebih tajam (Ibrahim et al. 2014).

\section{Tekstur}

Menurut Winarno (1997), perubahan tekstur suatu bahan dapat merubah aroma dan rasanya. Hal ini dikarenakan tekstur akan mempengaruhi kecepatan timbulnya rangsangan terhadap sel olfaktori dan kelenjar air liur. Tekstur dari suatu produk bila dilihat secara fisik dapat mempengaruhi cita rasa makanan. Setyaningsih et al. (2010) menyatakan bahwa tekstur memiliki sifat kompleks dan terkait dengan struktur bahan yang terdiri dari tiga elemen, yaitu mekanik (kekerasan, kekenyalan), geometrik (berpasir, beremah), dan mouthfeel (berminyak, berair). Hasil pengamatan tekstur dapat dilihat pada gambar 6 dan 7 .

Berdasarkan Gambar Tekstur hasil pengujian kerang Darah untuk perlakuan dengan penambahan es batu air ekstrak rumput laut pada jam ke-0 hingga jam ke-6 tekstur daging kerang masih dalam keadaan standart dengan nilai 9-7.8 dan mengalami penurunan pada jam ke-9 dengan nilai 6 , kemudian pada perlakuan dengan penambahan es batu biasa dari jam ke-0 hingga jam ke-9 tesktur dari daging kerang masih dalam keadaan standart dengan nilai 9-7 dan mengalami penurunan pada jam ke12 dengan nilai 6.5, dan pada daging dengan perlakuan tanpa es batu dari jam ke0 hingga jam ke-6 tesktur daging masih keadaan standart dengan nilai 9-7.5 dan 
mengalami penurunan pada jam ke-9 dengan nilai 6.3 pada perlakuan ini mengalami penurunan yang cukup drastis pada jam ke-18 menuju jam ke-21 dengan nilai 4-2.9. Hal ini diungkapkan pula oleh Alik
(2014) bahwa tekstur merupakan faktor yang berpengaruh terhadap penilaian, karena tekstur suatu makanan akan terasa saat konsumen memakannya.

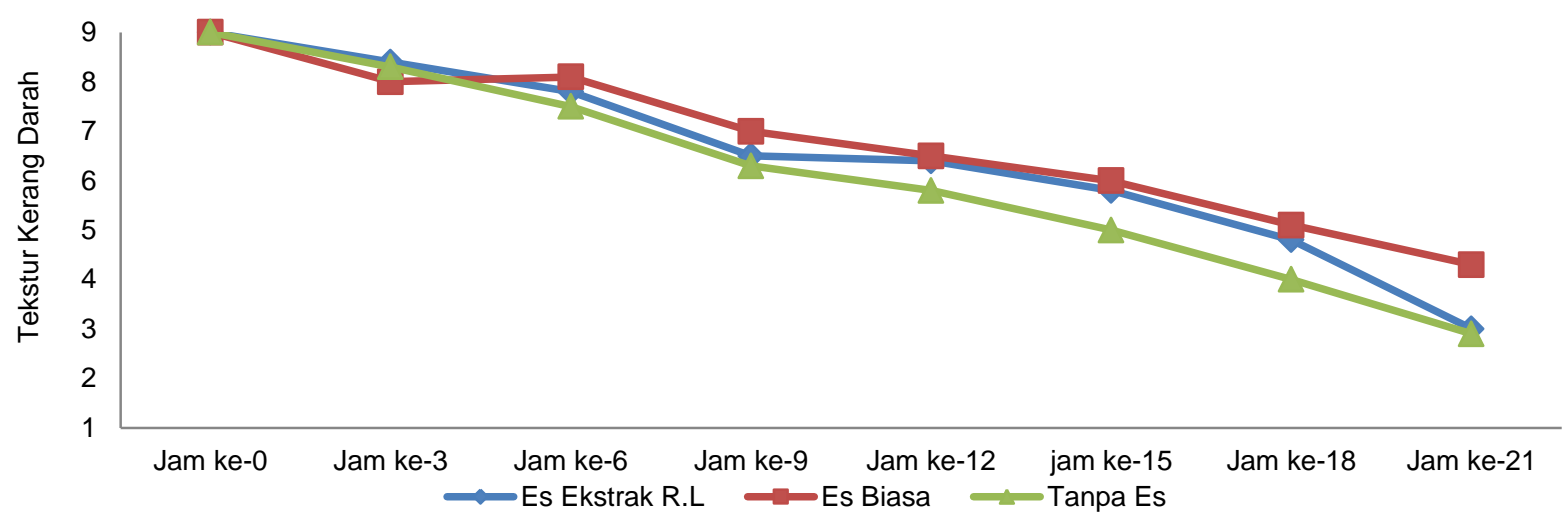

Gambar 6. Tekstur Kerang Darah

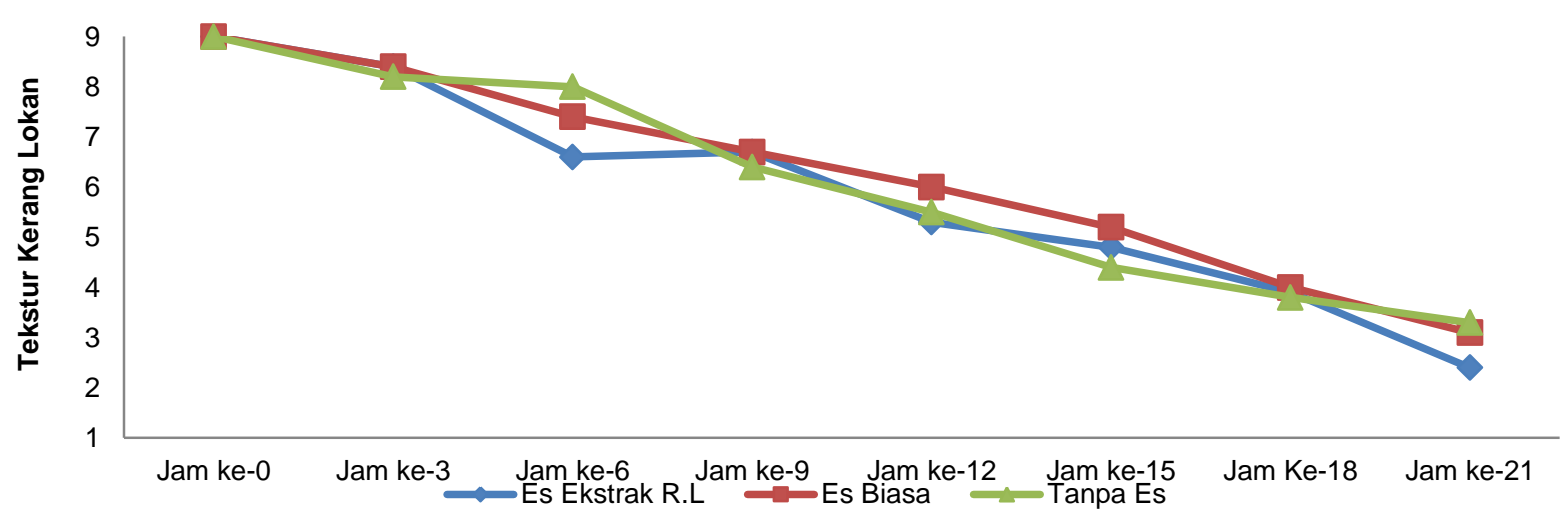

Gambar 7. Tekstur Kerang Lokan

Kemudian untuk Gambar tekstur untuk kerang yang menggunakan es biasa pengujian kerang Lokan menunjukkan bahwa dari jam ke-0 sampai jam ke-3 pada kerang yang menggunakan es ekstrak rumput laut masih terlihat segar karena dari angka 9 menurun menjadi 8,4 dan pada jam ke-6 sampai jam ke-21 sudah terlihat tidak segar. Kerang yang menggunakan es biasa dari jam ke-0 sampai jam ke-3 masih terlihat segar dari angka 8,6 menurun menjadi 7,8, dan pada kerang yang tidak menggunakan es juga dari jam ke- 0 sampai jam ke- 6 yang masih terlihat segar dari angka 9 menjadi 8 . Sedangkan dari jam ke-3 sampai jam ke-9

dan tanpa es sudah terlihat tidak segar lagi.

Menurut Standar Nasional Indonesia (2009), nilai mutu daging kerang minimal 7. Menurut Mustar (2013), dalam pengujian organoleptik terutama untuk penerimaan terhadap suatu produk, yang paling diutamakan yakni dari segi rasa, meskipun dalam pengujian, kesan pertama yang umumnya dilihat yakni pada parameter warna. Pada produk yang memiliki nilai baik pada parameter warna, aroma dan tekstur akan tetapi memiliki cita rasa yang tidak disukai maka produk tersebut belum dapat diterima. Dari hasil keduanya nilai terbaik 
kerang Darah ada pada perlakuan es batu semakin tinggi. Sama halnya kerang dengan biasa dan nilai terbaik kerang Lokan pada perlakuan es batu menghasilkan lebih banyak perlakuan tanpa es batu.

\section{Water Holding Capacity (WHC)}

Water Holding Capacity (WHC), didefinisikan sebagai kemampuan daging untuk menahan airnya, misalnya pemotongan daging, pemanasan, penggilingan, dan tekanan. Daging juga mempunyai kemampuan untuk menyerap air secara spontan dari lingkungan yang mengandung cairan. Berdasarkan Tabel, WHC yang paling sedikit menyerap air adalah daging kerang dengan perlakuan tanpa es batu dengan nilai kerang Darah 6.69\% dan kerang Lokan 4.13\% dikarena daging kerang tidak menyerap air lebih dari adanya penambahan es batu air ekstrak rumput laut maupun es batu biasa, dan daging kerang dengan perlakuan menggunakan es batu air ekstrak rumput laut memiliki daya serap air yang paling banyak yaitu kerang Darah dengan nilai $7.94 \%$ dan kerang Lokan $10.00 \%$. untuk nilai daya serap dengan perlakuan es batu biasa kerang darah $7.73 \%$ dan kerang Lokan $7.04 \%$. Menurut Akhadiyah dan Budi (2011), perlakuan konsentrasi ekstrak jahe dan lama perendaman memberikan pengaruh yang sangat nyata terhadap WHC, namun interaksi antara kedua faktor ini tidak memberikan pengaruh yang nyata terhadap WHC. Hasil penelitian menunjukkan bahwa semakin tinggi konsentrasi ekstrak jahe dan semakin lama perendaman menghasilkan WHC yang kandungan air pada daging.

\section{Nilai pH}

Kesegaran kerang dapat juga dilihat dari hasil mengukur $\mathrm{pH}$ dari daging kerang itu sendiri. Hasil uji pH dari kedua biota kerang dapat dilihat dari Tabel 2. Berdasarkan Tabel $\mathrm{pH}$ dari dua biota kerang yaitu kerang Darah dan kerang Lokan $\mathrm{pH}$ yang mendekati netral adalah kerang dengan perlakuan tanpa es batu untuk kerang Lokan bernilai 5.9 dan kerang Darah bernilai 6.2 dan $\mathrm{pH}$ terendah didapatkan kerang Lokan dan Darah dengan perlakuan es batu air ekstrak rumput laut dengan nilai yang sama yaitu 5.1 , sedangkan perlakuan es batu biasa kerang Lokan 5.4 dan kerang Darah 5.3.

Adawyah (2007) menyatakan bahwa penurunan kualitas mutu ikan dapat dilihat dari segi fisik yaitu dengan menurunnya kesegeran ikan dan nilai organoleptik yang rendah $(<7)$. Sedangkan penilaian dari segi kimiawi dapat diukur dari nilai derajat keasaman $(\mathrm{pH})$, dimana nilai $\mathrm{pH}$ ikan yang sudah mundur mutu memiliki pH basa. Dari tiga perlakuan didapatkan $\mathrm{pH}$ dibawah netral atau dengan kategori asam. Hal ini dijelaskan oleh Wahab (2003), bahwa pH asam menjadikan unsur kation logam menghilang karena proses pelarutan.

Tabel 1. Nilai WHC Kerang Lokan dan Kerang darah

\begin{tabular}{cccc}
\hline Parameter & \multicolumn{3}{c}{ Perlakuan } \\
\cline { 2 - 4 } & Es Batu Ekstrak Rumput Laut & Es Batu Biasa & Tanpa Es Batu \\
\hline Kerang Lokan & 10,0025 & 7,0411 & 4,1308 \\
Kerang Darah & 7,9493 & 7,7383 & 6,6903 \\
\hline \multirow{2}{*}{ Tabel 2. Nilai pH Kerang Lokan dan Kerang Darah } & & \\
\hline \multicolumn{2}{c}{ Parameter } & & \\
\cline { 2 - 4 } & Es Batu Rumput Laut & Es batu Biasa & Tanpa Es Batu \\
\hline Kerang Lokan & 5,1 & 5,4 & 5,9 \\
Kerang Darah & 5,1 & 5,3 & 6,2 \\
\hline
\end{tabular}




\section{KESIMPULAN}

Penambahan es batu air hasil ekstraksi rumput laut Eucheuma cottonii tidak memberikan efek yang lebih baik untuk kemunduran mutu dari kedua biota kerang yaitu kerang Darah dan kerang Lokan.

\section{DAFTAR PUSTAKA}

Adawyah, R. 2007. Pengolahan dan Pengawetan Ikan. PT Bumi Aksara. Jakarta

Alimuddin, A. 2013. Sifat-Sifat Fisik Daging Sapi Segar (PH, Daya Ikat Air, Susuk Masak, \& Keempukan).

Akhadiyah, A., Budi, S. 2011. Water holding capacity, Kadar Protein, dan Kadar air Dendeng Sapi pada berbagai konsentrasi ekstrak jahe dan lama Perendaman yang Berbeda. Jurnal IImu dan Teknologi Hasil Ternak. Vol.6. Hal 41-46.

Alik, A. T., Sukmiwati, M., Sari. I. 2014. A Study On Consumer Acceptance Of Tilapia Abon (Oreochromis Niloticus) With The Addition White Oyster Mushroom (Pleurotus Ostreatus).

[BSN] Badan Standardisasi Nasional. 2009. Tentang Daging Kerang Bagian 1: Spesifikasi. Badan Standarisasi Nasional, Jakarta. SNI 3460.1:2009.

Budiyanto, D., Ismanadji, I., Aji U, S., Sugiri. 1990. Laporan Uji Coba Depurasi Kerang-kerangandan Kaitannya dengan Pengalengan. BBPMHP. Jakarta.

Dwyana Z, Johannes E. 2012. Uji Efektivitas Ekstrak Kasar Alga Merah Eucheuma Cottonii Sebagai Antibakteri Terhadap Bakteri Patogen.

Gimin, R., Mohan, R., Thinh, L. V., Griffiths, A. D. 2004. The relationship of shell dimensions and shell volume to live weight and soft tissue weight in the mangrove clam, Polymesoda erosa (Solander, 1786) from northern Australia. NAGA, WorldFish Center Quarterly, 27p.

Hafizah, I. 2015. Uji aktivitas antibakteri ekstrak metanol rumput laut Eucheuma sp. pada berbagai tingkat konsentrasi terhadap pertumbuhan bakteri Escherichia coli dan Staphylococcus aureus. [Skripsi]. Kendari (ID): Universitas Haluoleo.

Hasan, U.,Wahyuningsih, H dan Jumilawati, E. 2014. Kepadatan Dan Pola Pertumbuhan Kerang Lokan (Geloina Erosa, Solander 1786) Di Ekosistem Mangrove Belawan. Jurnal Perikananan Dan Kelautan Issn 08537607. Universitas Sumatera Utara. Medan. Diterima (15 September 2014) dan disetujui (25 Juli 2017).

Irianto, H. E., Giyatmi, S. 2009. Teknologi pengolahan hasil perikanan. Jakarta : Universitas Terbuka.

Iskandar, Y., Dewi Rusmiati, dan Rini Rusma Dewi. 2005. Uji aktivitas Antibakteri Ekstrak Etanol Rumput Laut (Eucheuma cottonii) terhadap Bakteri Escherichia coli dan Bacillus cereus [Skripsi]. Jurusan Farmasi Fakultas Mipa Universitas Padjadjaran Jatinangor, Sumedang.

Iskandar, Y., Rusmiati, D., Dewi, R. R. 2009. Uji Aktivitas Antibakteri Ekstra Etanol Rumput Laut Eucheuma cottonii Terhadap Bakteri Escherichia coli dan Bacillus cereus. Fakultas MIPA Jurusan Farmasi. Jatinangor, Sumedang.

Karim, M., Aspari, D. N. F. 2015. Pengaruh penambahan tepung karaginan terhadap mutu kekenyalan bakso ikan gabus. Jurnal Balik Diwa. 6(2): 41-49

Muhammad, R., Putri, R. M. S., Apriandi, A. 2018. Karakteristik Asam Amino dan Logam Berat pada Daging Kerang 
Lokan (Geloina erosa) Segar dan Rebus dari Perairan Pesisir Tanjung Unggat Kota Tanjungpinang. Jurusan Teknologi Hasil Perikanan, Fakultas IImu Kelautan dan Perikanan, Universitas Maritim Raja Ali Haji.

Mustar. 2013. "Studi Pembuatan Abon Ikan Gabus (Ophiocephalus Striatus) sebagai Makanan Suplemen (Food Suplement)". Skripsi. Makassar: Fakultas Pertanian Universitas Hasanuddin, 2013.

Nurjanah., Purwatiningsih, S., Salamah, E., Abdullah, A. 2010. Karakteristik protein dan asam amino kijing lokal (Pilsbryoconcha exilis) dari Situ Gede, Bogor. Prosiding Seminar Nasional Perikanan Indonesia 2010, Melindungi Nelayan dan Sumberdaya Ikan.

Kementrian Kelautan Perikanan. 2017. Statistik sektoral. Data Produksi Kelautan dan Perikanan Indonesia. Jakarta (ID): KKP.

Kementrian Kelautan Perikanan. 2018. Statistik sektoral. Data Produksi Kelautan dan Perikanan Indonesia. Jakarta (ID): KKP.

Rasidi, Astuti, I. R., Rusmaedi. 2007. Aspek biologi, Distribusi dan pengelolaan Sumberdaya Kerang Darah (Anadara granosa). Jakarta: Riset perikanan budidaya.

Rochima I, Rizki A. 2009. Pengaruh suhu pengeringan terhadap karakteristik kimiawi fillet lele dumbo asap cair pada penyimpanan suhu ruang. Jurnal Bionatura 11(1): 21- 36.

Setyaningsih, D., Apriyantono, A., Puspita, S. M. 2010. Analisis sensori untuk Industri Pangan dan Agro. Bogor (ID): IPB Press.

Soekarto, S. T. 1985. Penilaian Organoleptik Untuk Industri Pangan dan Hasil Pertanian. Penerbit Bharata Karya Aksara. Jakarta.
Stein, L. H., Hirmas, E., Mevik, M. B., Karlsen, R., Nortved, R., Bencze, A. M., Sunde, J., Kiessling, A. 2005. The effects of stress and storage temperature on thecolour and texture of pre-rigor filleted farmed cod (GadusmorhuaL). Aquaculture Research 36:1197- 1206.

Sartika, R., Melki., Purwiyanto, A. I. S. 2013. Aktivitas Antibakteri Ekstrak Rumput Laut Eucheuma cottoni terhadap Bakteri Escherichia coli, Staphylococcus aureus, Vibrio cholera dan Salmonella typhosa. Program Studi IImu Kelautan FMIPA Universitas Sriwijaya, Inderalaya, Indonesia. Maspari Journal, 5 (2), 98-103.

Suaniti, M. 2007. Pengaruh Edta Dalam Penentuan Kandungan Timbal Dan Tembaga Pada Kerang Hijau (Mytilus viridis). J. Ecotrophic, 2(1):19075626.

Sugiyono. 2011. Metode Penelitian Kuantitatif, Kualitatif dan R\&D. Bandung: Afabet

Suwetja, I. K. 2007. Biokimia Hasil Perikanan. Jilid III. Rigormortis, TMAO, dan ATP. Fakultas Perikanan dan IImu Kelautan. Uversitas Sam Ratulangi Manado.

Wahab, H. M. 2003. Pengantar Biokimia. Penerbit Banyumedia Publising. Semarang. $179 \mathrm{hlm}$.

Widowati, I., J. Suprijanto., R, Hartati., Dwiono, S.A.P. 2005, Hubungan dimensi cangkang dengan berat kerang totok (Polymesoda erosa) dari Segara Anakan Cilacap, 1(5): 55-58.

Winarno, F. G. 1997. Kimia Pangan Dan Gizi. Gramedia Pusat Utama. Jakarta.

Winarno, F.G. 2002. Kimia Pangan dan Gizi. PT. Gramedia Pustaka Utama: Jakarta. 
Zakaria, R. 2008. Kemunduran Mutu Ikan Gurami (Osphronemus gouramy) Pasca Panen pada Penyimpanan Suhu Chilling. [Skripsi] Teknologi Hasil Perikanan. IPB. Bogor. Bogor.
Zuhrina. 2011. "Pengaruh Penambahan Tepung kulit pisang Raja (Musa Paradisiaca) terhadap daya terima kue Donat". Skripsi. Medan: Universitas Sumatra Utara. 2011. 